\title{
Forschende
}

Komplementärmedizin Wissenschaft - Praxis - Perspektiven

Research in Complementary Medicine Research - Practice - Perspectives

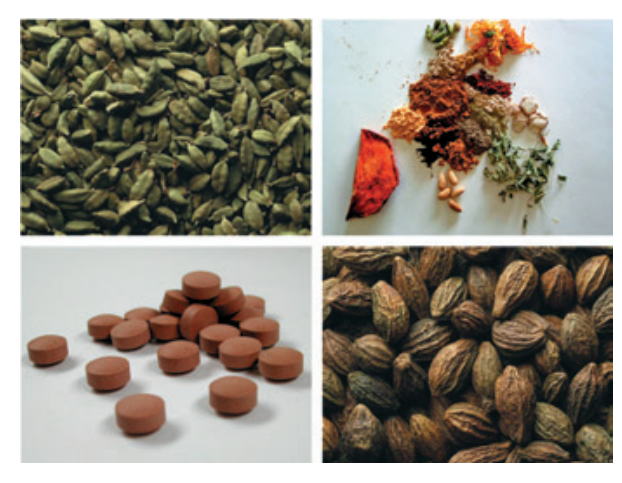

\section{Tibetische Heilmittel bei chronischen Erkrankungen}

Herausgeber: R. Saller, Zürich 